\title{
PENGEMBANGAN BAHAN AJAR MATEMATIKA BERBASIS KEARIFAN LOKAL UNTUK SISWA SMP KELAS VIII
}

\author{
${ }^{1}$ Neneng Farhatin, ${ }^{2}$ Heni Pujiastuti, ${ }^{3}$ Anwar Mutaqin \\ ${ }^{1,2,3}$ Universitas Sultan Ageng Tirtayasa, J1. Raya Jakarta KM.4, Panancangan, Kec. Serang, Kota Serang, Banten \\ 42124, (0254) 280330, Indonesia \\ e-mail: nfarhatin05@gmail.com
}

\begin{abstract}
Abstrak
Penelitian ini bertujuan untuk mengembangkan bahan ajar matematika berbasis kearifan lokal dikarenakan belum banyak tersedianya bahan ajar matematika berbasis kearifan lokal dan bahan ajar ini diharapkan layak untuk digunakan. Pengembangan bahan ajar berbasis kearifan lokal dalam pembelajaran matematika pada materi persamaan linier dua variabel. Metode dari penelitian ini adalah Research and Development Model ADDIE. Langkah-langkah pengembangan yang ditempuh adalah (1) analyze (analisis), (2) design (perancangan), (3) development (pengembangan), (4) implementation (implementasi), (5) evaluation (evaluasi). Uji kelayakan berdasarkan penilaian dari para ahli menunjukan bahwa bahan ajar berbasis kearifan lokal memperoleh kategori sangat baik dengan hasil penilaian dan validasi oleh ahli materi yaitu $80.00 \%$ dan hasil penilaian dan validasi oleh ahli media $85 \%$ sehingga bahan ajar berbasis kearifan lokal ini layak untuk digunakan. Uji kelayakan berdasarkan angket respon siswa menunjukkan bahwa bahan ajar matematika berbasis kearifan lokal ini memperoleh kategori sangat baik dengan persentase $81 \%$ sehingga bahan ajar matematika berbasis kearifan lokal layak digunakan.
\end{abstract}

Kata Kunci: bahan ajar, kearifan lokal, persamaan linier dua variabel.

\begin{abstract}
This study aims to develop mathematics teaching materials based on local wisdom because there is not much available mathematics teaching materials based on local wisdom and this teaching material is expected to be feasible to use, therefore, the researcher makes a work of local wisdom based teaching materials mathematics learning in the subject of equations linear two variables. The method of this research is the ADDIE Research and Development Model. Development steps taken are (1) analyze (analysis), (2) design, (3) development, (4) implementation, (5) evaluation. The due diligence based on the assessment of the experts shows that the local wisdom-based teaching materials get very good category with the results of the assessment and validation by the material experts that is $80.00 \%$ and the results of the assessment and validation by the media experts $85 \%$ so that the local wisdom-based teaching materials are feasible to use. The feasibility test based on student response questionnaires showed that the local wisdom-based mathematics teaching material obtained a very good category with a percentage of $81 \%$ so that the local wisdom-based mathematics teaching material was suitable for use.
\end{abstract}

Keywords: teaching materials, local wisdom, two variables linear equation

\section{PENDAHULUAN}

Beragam kebudayaan yang dimiliki negara Indonesia tersebar dari Sabang sampai Merauke. Kebudayaan tidak dapat dipisahkan dari masyarakat Indonesia. Pendidikan adalah salah satu unsur kebudayaan. Melalui pendidikan, kebudayaan dapat dikembangkan dan diwariskan, sebaliknya ciri-ciri dan pelaksanaan pendidikan ditentukan oleh kebudayaan (Nurrahmi, 2017).

Tilaar (Wibowo \& Gunawan, 2015:12) menegaskan " agar pendidikan jangan sampai tidak berbudaya, pendidikan jangan sampai dipisahkan dengan kebudayaan. Maka kurikulum 
harus menjembatani bahkan merekomendasi peserta didik untuk berinteraksi dan bekerjasama dengan lingkungan sekitarnya”.

Sumarmi \& Amiruddin (2014: 22) mengemukakan "kearifan lokal merupakan pengetahuan lokal yang digunakan oleh masyarakat untuk bertahan hidup dalam suatu lingkungannya yang menyatu dengan sistem kepercayaan, norma, budaya diekspresikan dalam tradisi yang dianut dalam jangka waktu yang lama”.

Salah satu komponen penunjang untuk pembelajaran adalah bahan ajar sebagai sumber belajar mengajar dan sebagai pegangan bagi pendidik dan peserta didiknya. Dengan demikian pengembangan bahan ajar pada pembelajaran matematika, diupayakan dapat menumbuh kembangkan kecerdasan, keterampilan serta membentuk karakter siswa dengan melestarikan nilai nilai budaya luhur dan kearifan lokal sebagai warisan dari nenek moyang.

"Bahan ajar harus disusun secara sistematis, menarik, aspek keterbacaan tinggi, mudah dicerna, dan mematuhi aturan penulisan yang berlaku" (Nurmita F, 2017). Maka dari itu bahan ajar yang tersusun secara sistematis akan mempermudah peserta didik dalam menerima materi, sehingga mendukung ketercapaian tujuan pembelajaran.

Salah satu upaya yang dapat dilakukan dalam memasukkan nilai-nilai kearifan lokal ke dalam mata pelajaran matematika adalah dengan cara merancang, membuat dan mengembangkan bahan ajar berbasis nilai kearifan lokal. Bahan ajar yang ada disaat ini belum mengungkapkan kelokalan yang merupakan kekayaan daerah, itu artinya belum adanya bahan ajar yang berbasis kearifan lokal.

Berdasarkan hal tersebut, pengembangan bahan ajar yang berbasis kearifan lokal sangatlah diperlukan. Hal ini merupakan bentuk keleluasaan guru untuk mengembangkan keunikan, budaya, keunggulan yang berbasis kearifan lokal (Ferdianto \& Setiyani, 2018).

Untuk itu pengembangan bahan ajar berbasis kearifan lokal sangatlah penting dalam mengembangkan keunikan, budaya, dengan pendidikan berbasis kearifan lokal memberikan bekal pengetahuan, ketrampilan dan perilaku kepada peserta didik agar mereka memiliki wawasan yang mantap tentang keadaan lingkungan dan kebutuhan masyarakat sesuai dengan nilai-nilai/aturan yang berlaku didaerahnya dan mendukung pembangunan daerah serta pembangunan nasional.

Banten memiliki keunikan dan menyimpan kekayaan budaya lokal yang memiliki potensi untuk terus dilestarikan hingga saat ini. Berbagai kearifan budaya lokal tercermin pada aspek budaya, maupun hubungan sosial kemasyarakatan yang masih lestari keberadaannya diantaranya adalah wisata sejarah, alat musik tradisional, makanan tradisional, permainan

Prima, Vol. 4, No. 1, Januari 2020, 33-45. 
tradisional, kesenian dan berbagai macam aktivitas yang sudah membudaya (Budaya, Pariwisata, \& Banten, n.d.).

Kearifan lokal Banten menjadi inovasi dalam pembelajaran matematika, sekaligus pengenalan dan pelestarian terhadap budaya lokal Banten. Potensi budaya lokal Banten sangatlah penting untuk dijadikan sebagai sumber pembelajaran di sekolah agar peserta didik dapat mengenal nilai nilai budaya lokal dan memberi kesadaran untuk membangun sikap peserta didik bahwa potensi daerah yang kaya perlu dijaga dan dilestarikan. Adapun tujuan dari penelitian ini adalah :

1. Untuk menghasilkan bahan ajar matematika yang berbasis kearifan lokal untuk siswa SMP kelas VIII.

2. Untuk mengetahui apakah bahan ajar matematika berbasis kearifan lokal untuk SMP kelas VIII layak digunakan dalam pembelajaran matematika.

Berdasarkan uraian di atas, pada tulisan ini akan dipaparkan tentang bagaimana mengembangkan bahan ajar matematika berbasis kearifan lokal dalam proses pembelajaran.

\section{METODE PENELITIAN}

Penelitian ini merupakan penelitian dan pengembangan atau research and development (R\&D), adapun metode R\&D menurut (Sugiyono, 2017) adalah "sebuah metode penelitian yang digunakan untuk menghasilkan produk baru, dan menguji keefektifan produk tersebut". Perangkat pembelajaran yang dikembangkan dalam penelitian ini adalah bahan ajar materi persamaan linier dua variabel berbasis kearifan lokal Banten.

Penelitian ini menggunakan desain penelitian ADDIE yaitu analysis, design, development, implementation, and evaluation. Model pengembangan yang ADDIE dipilih dikarenakan model sangat sederhana tetapi memiliki implementasi yang sistematis, mudah dipelajari dan mudah dipraktikan dalam pengembangan media pembelajaran dan terutama dapat mengevaluasi dan merevisi secara terus menerus dalam setiap fase yang dilalui sehingga produk yang dihasilkan valid.

Penelitian dilakukan pada siswa kelas VIII SMPN 3 Pandeglang bulan Mei 2019 menggunakan angket dan ujicoba skala terbatas. Subjek dalam penelitian ini adalah subjek uji ahli dan subjek coba produk. Untuk subjek uji ahli terdiri dari masing-masing lima orang ahli yaitu dari ahli materi, dan ahli media. Sedangkan untuk uji coba produk dilakukan terhadap 20 peserta didik SMP Negeri 3 Pandeglang kelas VIII. Adapun tahapan yang terdapat dalam alur penelitian tersebut adalah sebagai berikut: 
1. Analysis (analisis)

Analisis kebutuhan dilakukan dengan terlebih dahulu menganalisis keadaan bahan ajar sebagai informasi utama dalam pembelajaran serta ketersediaan bahan ajar yang mendukung terlaksananya suatu pembelajaran. Pada tahap analisis kegiatan yang dilakukan antara lain:

a. Mengidentifikasi masalah dan menganalisis kompetensi yang harus dikuasai oleh siswa, seperti penentuan kompetensi dasar dan tujuan pembelajaran.

b. Menganalisis karakteristik siswa berkenaan dengan pengetahuan, sikap dan keterampilan.

c. Menganalisis materi yang relevan untuk pencapaian kompetensi yang diinginkan dimiliki oleh siswa

d. Mengumpulkan berbagai sumber yang relevan untuk memperkaya bahan materi.

\section{Design (rancangan)}

Setelah melakukan analisis kebutuhan dilanjutkan dengan mendesain bahan ajar, dimana produk yang akan dikembangkan adalah merupakan titik temu adanya kebutuhan berdasarkan penemuan di lapangan serta kemampuan dalam mengembangkan produk tersebut. Tahap ini bertujuan untuk menyiapkan suatu rancangan bahan ajar yang akan dikembangkan dengan membuat format dari awal pembelajaran sampai ahir pembelajaran.

3. Development (pengembangan)

Pengembangan adalah proses mewujudkan desain yang telah dirancang menjadi produk yang nyata. Satu langkah penting dalam tahap pengembangan adalah uji coba sebelum diimplementasikan (Aka, 2013).

Produk yang akan dikembangkan berupa bahan ajar yang akan digunakan oleh guru matematika berbasis kearifan lokal. Bahan ajar yang akan dicetak berbentuk buku paket dengan materi dan desain pembelajarannya di peruntukkan untuk SMP kelas VIII semester ganjil yang mengacu pada kurikulum 2013 dan desain dan materi pembelajaran matematika SMP kelas VIII semester ganjil yang berbasis kearifan lokal.Dengan harapan produk ini dapat membantu guru dalam kegiatan pembelajaran dikelas dan siswa dapat mengenal lebih dalam lagi budaya daerah khususnya budaya Banten.

Pada tahap pengembangan peneliti mencari dan mengumpulkan segala sumber referensi yang dibutuhkan untuk pengembangan materi dan tujuan yang sesuai dengan pembelajaran dan juga pada pengembangan ini untuk mengetahui dan menilai apakah produk bahan ajar sudah layak yang dikembangkan. Ahli yang dilibatkan dalam pengembangan produk ini masing 
masing ada lima orang ahli, yaitu 5 orang ahli materi dan 5 orang ahli media. Berikut kisi kisi angket yang diberikan kepada setiap ahli.

Tabel 1. Kisi-Kisi Angket Uji Ahli

\begin{tabular}{ccl}
\hline No. & Penguji & \multicolumn{1}{c}{ Aspek Penilaian } \\
\hline 1. & Ahli Materi & $\begin{array}{l}\text { Kelayakan isi dan Penyajian } \\
\text { Penilaian Berbasis Kearifan Lokal } \\
\end{array}$ \\
& Penilaian ahli bahasa \\
2. & Ahli Media & Penilaian Kegrafikan
\end{tabular}

4. Implementasi

Implementasi dalam penelitian ini merupakan proses uji coba bahan ajar dalam pembelajaran matematika di kelas. Bahan ajar dan instrumen yang telah direvisi berdasarkan masukan dari validator dan dinyatakan layak maka dapat mulai di uji cobakan di sekolah yang menjadi objek penelitian. Penerapan bahan ajar di dalam kelas dilakukan untuk mengetahui keefektifan dan kepraktisan dari bahan ajar.

5. Evaluasi

Evaluasi merupakan langkah terakhir dari model ADDIE. Tahap ini merupakan sebuah proses yang dilakukan untuk memberikan nilai terhadap produk yang dikembangkan. Tahap evaluasi bertujuan untuk mengetahui beberapa hal, yaitu sikap siswa terhadap produk yang dikembangkan secara keseluruhan, serta peningkatan kompetensi dalam diri siswa, yang merupakan dampak dari penggunaan produk yang dikembangkan (Aka, 2013). Masukan dan saran berasal dari pengguna bahan ajar yaitu guru dan siswa. Hasil validasi ahli dan uji coba lapangan dianalisis dengan menghitung persentase (\%) skor yang diperoleh dari semua ahli dan responden.

\section{HASIL DAN PEMBAHASAN}

Hasil utama dari penelitian dan pengembangan ini adalah bahan ajar matematika berbasis kearifan lokal untuk siswa SMP kelas VIII. Proses yang dilakukan dalam pengembangan ini meliputi Tahap analisis merupakan langkah paling awal yang dilakukan dalam penelitian ini. Tahap analisis dalam penelitian ini meliputi:

1. Tahap Analisis (Analysis )

Analisis kebutuhan guru terhadap bahan ajar dilakukan untuk mengidentifikasi dan mengeksplorasi kebutuhan terhadap buku ajar bagi guru yaitu dengan menyebar angket kepada guru matematika yang digunakan di sekolah. Hasil analisis angket digunakan untuk 
mengetahui persepsi guru terhadap buku teks pelajaran matematika berbasis kearifan lokal pada materi persamaan linier dua variabel. Berikut ini rekap hasil analisis kebutuhan guru terhadap bahan ajar berbasis kearifan lokal.

Tabel 2. Persepsi dan Hasil Analisis Kebutuhan Guru

\begin{tabular}{llc}
\hline No. & \multicolumn{1}{c}{ Aspek Analsis Kebutuhan } & \multicolumn{1}{c}{$\begin{array}{c}\text { Persentase } \\
(\%)\end{array}$} \\
\hline 1 & Kebutuhan terhadap bahan ajar & $80 \%$ \\
2 & $\begin{array}{l}\text { Kebutuhan terhadap penguatan nilai-nilai } \\
\text { kearifan lokal }\end{array}$ & $83,33 \%$ \\
3 & $\begin{array}{l}\text { Kebutuhan terhadap buku ajar peserta didik } \\
\text { yang berbasis kearifan lokal } \\
4\end{array}$ & $\begin{array}{l}\text { Ketertarikan terhadap buku ajar peserta } \\
\text { didik yang berbasis kearifan lokal }\end{array}$ \\
\hline
\end{tabular}

2. Rancangan Produk (Design product)

Produk buku bahan ajar berbasis kearifan lokal dan kemampuan abad 21 dalam pembelajaran matematika SMP pada materi persamaan linear dua variable yang dihasilkan meliputi:

a. Cover/Sampul Buku

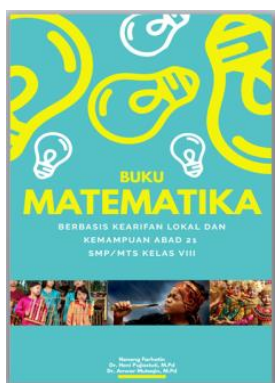

Cover depan

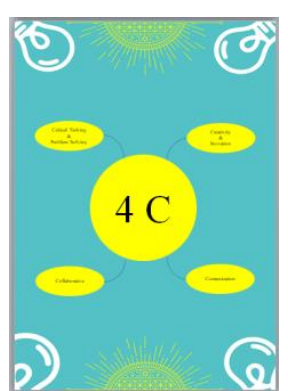

Cover belakang

b. Kata Pengantar dan Daftar Isi

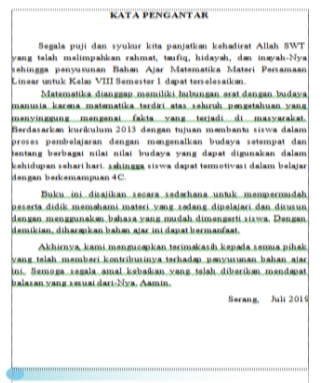

Kata pengantar

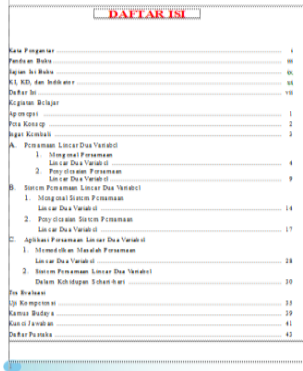

Daftar isi

Prima, Vol. 4, No. 1, Januari 2020, 33-45. 
c. Tampilan informasi awal mengenai buku.

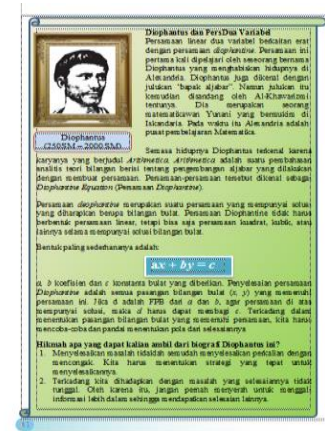

Literasi

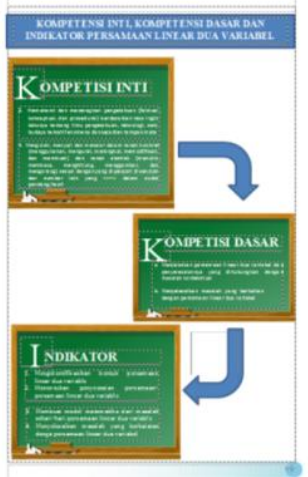

Kompetensi yang akan dicapai

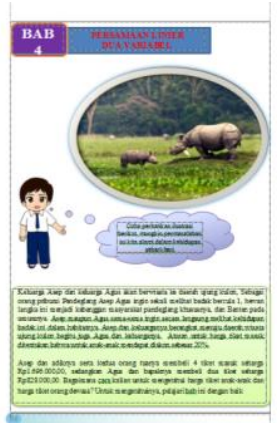

Awal Materi

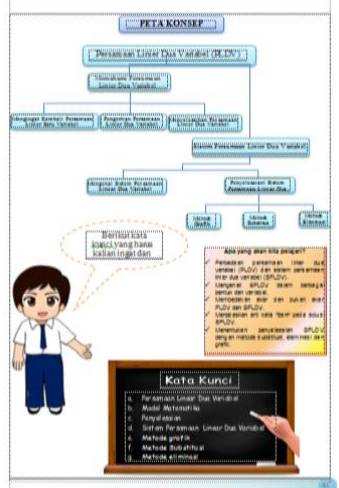

Peta Konsep

d. Permasalahan pada setiap sub kegiatan pembelajaran

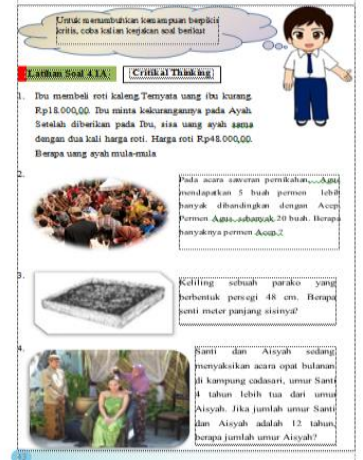

Masalah 1

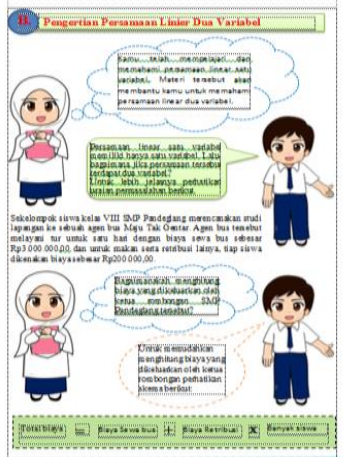

Masalah 2 
e. Nilai-nilai kearifan lokal

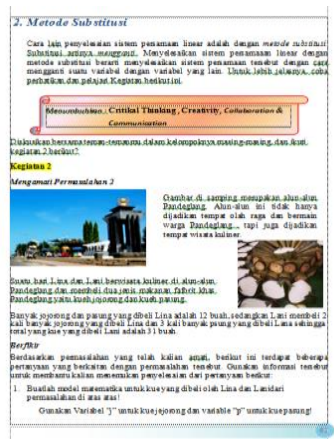

f. Bagian akhir bahan ajar

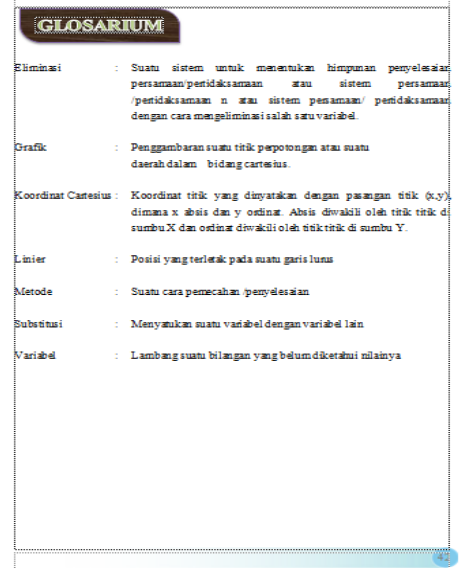

Glosarium

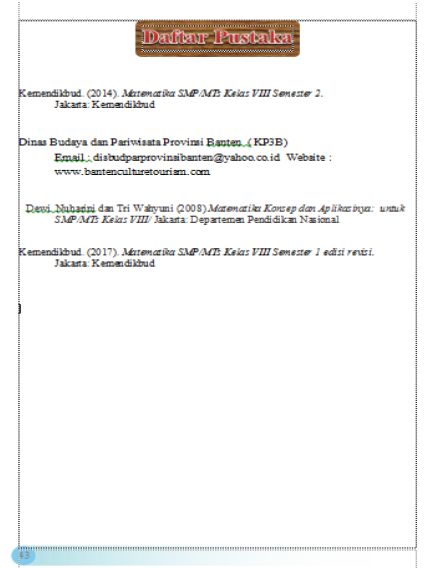

Daftar Pustaka

\section{Tahap Pengembangan (Development)}

a. Instrumen Uji Ahli

Instrumen uji ahli digunakan untuk menilai bahan ajar yang dikembangkan sudah layak atau belum berdasarkan penilaian ahli. Instrumen uji ahli yang peneliti gunakan diambil dari instrument uji ahli yang dikeluarkan oleh Badan Standar Nasional Pendidikan (BSNP) tentang pengembangan bahan ajar.

b. Revisi Desain

Revisi desain dari bahan ajar berorietasi penguatan kearifan lokal dan kemampuan abad 21 dalam pembelajaran matematika SMP pada materi persamaan linear dua variabel yang dikembangkan sesuai saran dari penguji ahli yang telah dilakukan pada tahap sebelumnya. Berikut ini beberapa saran yang diberikan oleh ahli. 
Tabel 3. Rekapitulasi Saran dan Kesimpulan Ahli

\begin{tabular}{clll}
\hline No & Penguji & \multicolumn{1}{c}{ Saran } & Keterangan \\
\hline Ahli & $\begin{array}{l}\text { Memotivasi siswa dapat } \\
\text { dilakukan dengan } \\
\text { memberikan contoh yang } \\
\text { akan rumit, jika tidak } \\
\text { mempelajari tujuan dalam } \\
\text { bab ini. }\end{array}$ & $\begin{array}{l}\text { Dapat digunakan } \\
\text { dengan revisi }\end{array}$ \\
& $\begin{array}{l}\text { Perbaiki beberapa soal yang } \\
\text { dikoreksi }\end{array}$ & $\begin{array}{l}\text { Dapat digunakan } \\
\text { dengan revisi }\end{array}$ \\
& Ahli & Warna harus dipercerah lagi & $\begin{array}{l}\text { Dapat digunakan } \\
\text { tanpa revisi }\end{array}$ \\
\hline
\end{tabular}

Berikut desain bahan ajar berbasis kearifan lokal sebelum revisi dan setelah revisi:
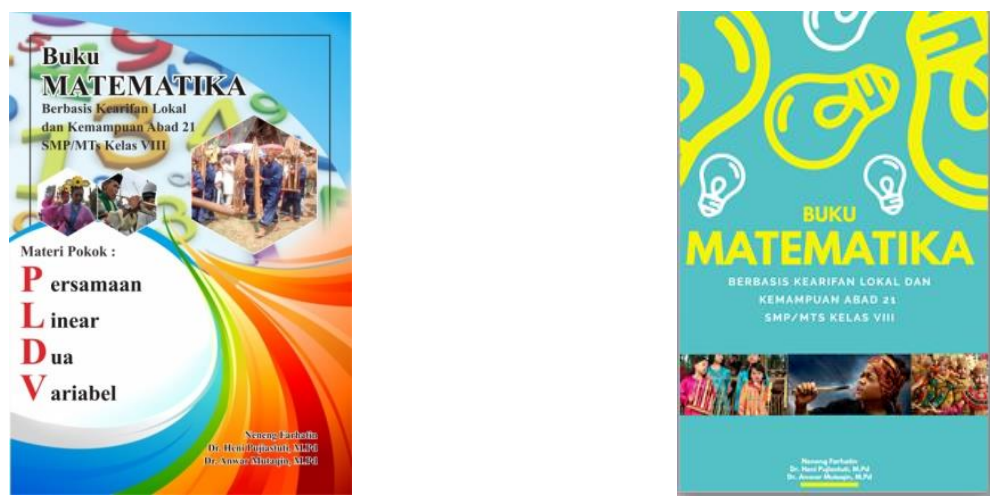

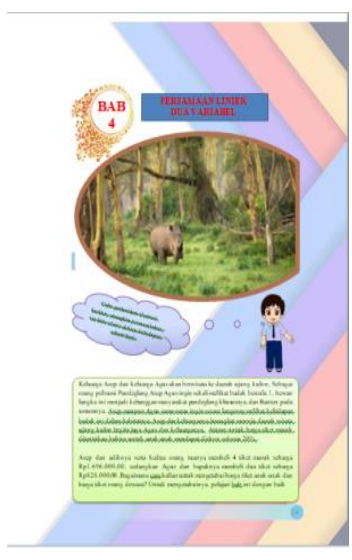

Sebelum revisi

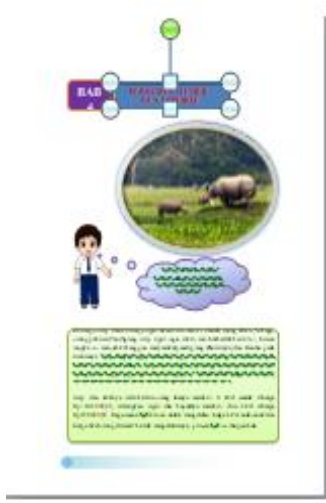

Setelah revisi

c. Instrumen uji coba produk

Instrumen uji coba produk ini dimaksudkan untuk melihat respon peserta didik ataupun guru terhadap bahan ajar yang dikembangkan. Ujicoba ini dilakukan dengan skala terbatas 
untuk peserta didik dilaksanakan hanya satu kali pertemuan kemudian mengisi angket, dan untuk guru dilakukan wawancara setelah menggunakan bahan ajar ini.

\section{Tahap Implementasi (Implementation)}

Bahan ajar yang dikembangkan divalidasi oleh 5 orang ahli materi dan 5 orang ahli media, serta diujicobakan kepada siswa melalui angket respon siswa.

a. Validasi kelayakan

Penilaian kelayakan bahan ajar persamaan linier dua variabel dilakukan oleh validator, yaitu 5 orang ahli materi dan 5 orang ahli media. Hasil pengembangan dalam penelitian ini adalah bahan ajar persamaan linier dua variabel berbasis kearifan lokal dinyatakan layak digunakan.

Tabel 4. Data Hasil Keseluruhan Penilaian dan Validasi Oleh Ahli Materi, dan Ahli Media

\begin{tabular}{clll}
\hline Jenis Ahli & Aspek & Persentase & Kategori \\
\hline Ahli Materi & Kelayakan Isi & $80.71 \%$ & Sangat \\
& Kelayakan & $80.36 \%$ & Baik \\
& Penyajian & $87.31 \%$ & Sangat \\
Kelayakan & $80.00 \%$ & Baik \\
Bahasa & & Sangat \\
& Penilaian & & Baik \\
& Kearifan Lokal & & Sangat \\
& Kelayakan & & Baik \\
& Kegrafikan & $85.00 \%$ & Sangat \\
Ahli Media & & & Baik \\
& Rata rata & & Sangat \\
& & $82.68 \%$ & Baik \\
\hline
\end{tabular}

Berdasarkan tabel persentase dari 5 aspek yang dinilai oleh ahli materi, dan ahli media, dapat disimpulkan bahwa penilaian secara keseluruhan dari 5 aspek tersebut oleh dua ahli sebesar $82.68 \%$ dengan kategori sangat baik. Berdasarkan hasil tersebut bahan ajar persamaan linear dua variable berbasis kearifan lokal matematika kelas VIII SMP ini dinyatakan layak digunakan di lapangan.

b. Respon siswa

Uji coba produk terhadap peserta didik ini dilakukan dengan tujuan untuk melihat respon peserta didik terhadap bahan ajar yang dikembangkan. Uji coba ini dilakukan terhadap 20 orang peserta didik kelas VIII B SMPN 3 Pandeglang. Uji coba yang dilakukan adalah ujicoba skala terbatas, sehingga hanya sebagian materi yang ada dalam bahan ajar yang dicoba, yaitu pada sub materi persamaan linear dua variabel. Data hasil yang diperoleh dari 
uji coba produk yaitu, bahan ajar yang diberikan bertampilan menarik, dan mudah dipahami.

Tabel 5. Rekapitulasi hasil uji coba produk

\begin{tabular}{llc}
\hline No. & \multicolumn{1}{c}{ Indikator Penilaian } & $\begin{array}{c}\text { Skor } \\
\text { Jumlah }\end{array}$ \\
\hline 1. & Rasa Senang bahan ajar yang \\
diberikan & \\
Motivasi belajar siswa setelah & menggunakan bahan ajar & 318 \\
Pemahaman manfaat & \\
pelajaran matematika setelah & 245 \\
& menggunakan bahan ajar & \\
& Total & \\
& Skor Maksimal & 810 \\
& Persentase respon & 1000 \\
\end{tabular}

\section{Evaluasi Produk}

Tahap ini adalah tahapan terakhir yaitu untuk merevisi kembali produk bahan ajar berbasis kearifan lokal dalam pembelajaran matematika SMP pada materi persamaan linear dua variabel berdasarkan masukan dari hasil ujicoba produk yang telah dilakukan pada tahap sebelumnya. Tetapi berdasarkan hasil ujicoba produk, peneliti dapat menyimpulkan bahwa produk yang dikembangkan sudah baik dan tidak ada yang harus direvisi kembali. Berdasarkan hasil validasi ahli, respon siswa dan perbaikan-perbaikan dapat disimpulkan bahan ajar persamaan linier dua variabel berbasis kearifan lokal yang dikembangkan telah memenuhi kriteria valid dan layak digunakan.

\section{SIMPULAN DAN SARAN}

\section{Simpulan}

Produk berupa bahan ajar berbasis kearifan local pada materi persamaan linier dua variabel ini dapat dikatakan layak digunakan dalam proses pembelajaran menurut beberapa hasil sebagai berikut:

1. Penelitian dan pengembangan ini menghasilkan suatu produk berupa buku matematika kurikulum 2013 berbasis kearifan lokal untuk SMP kelas VIII semester I pada materi persamaan linier dua variabel. Produk ini merupakan produk yang disusun dalam bentuk buku terdiri dari 43 halaman dengan komposisi berupa materi materi persamaan linier dua variabel yang disajikan dengan kearifan lokal budaya Banten. Materi tersebut disusun berdasarkan KI dan KD kurikulum 2013 serta mengacu pada proses belajar 
kurikulum 2013. Pada buku ini terdapat bahan amatan dan lembar kegiatan menemukan konsep, contoh masalah serta strategi penyelesainnya, latihan soal, dan evaluasi.

2. Uji kelayakan berdasarkan penilaian dari para ahli menunjukan bahwa bahan ajar berbasis kearifan lokal memperoleh kategori sangat baik dengan hasil penilaian dan validasi oleh ahli materi yaitu $80.00 \%$ dan hasil penilaian dan validasi oleh ahli media $85 \%$ sehingga buku berbasis kearifan lokal ini layak untuk digunakan.

3. Uji kelayakan berdasarkan angket respon siswa menunjukkan bahwa bahan ajar matematika berbasis kearifan lokal memperoleh kategori sangat baik dengan persentase $81 \%$ sehingga bahan ajar matematika berbasis kearifan lokal layak digunakan.

\section{Saran}

Berdasarkan hasil penelitian yang telah dilakukan, saran yang dapat disampaikan peneliti adalah sebagai berikut:

Bagi peneliti selanjutnya dalam menyusun buku yang memuat budaya kearifan lokal, agar lebih memperdalam lagi pengetahuan budaya lokal setempat untuk mempermudah penulisannya serta diharapkan dapat melakukan pengembangan buku matematika berbasis kearifan lokal pada materi yang lain.

\section{DAFTAR PUSTAKA}

Afifah N (2017). Pengembangan Modul Matematika Kurikulum 2013 Bermuatan Kebudayaan

Lokal Untuk Kelas VIII SMP/MTs Semester II Pada Materi Persamaan Linier dua Variabel Semarang: Universitas Islam Negeri Walisongo

Agus wibowo, \& Gunawan. (2015). Pendidikan Karakter Berbasis Kearifan Lokal Di Sekolah. Yogyakarta: Pustaka Pelajar.

Aka, K. A. (2013). Model - Model Pengembangan Bahan Ajar (Addie, Assure, Hannafin Dan Peck, Gagne And Briggs Serta Dick And Carry), Borg And Gall, 4d. (Online).

Budaya, D., Pariwisata, D. A. N., \& Banten, P. (n.d.). Seni Budaya Tradisional.

Daro, P. et al. (2011). Learning Trajectory in Mathematics. [Online]. Tersedia: http://files.eric.ed.gov/fulltext/ED519792.pdf. [25 Januari 2014]

Dias, C., Duarte, A., Ibanez, A., Rodrigues, D., Barros, D., Soares, J., ... Gutiérrez, M. (2013). Saved_Resource. Rev Esc Enferm USP, Vol. 47, pp. 1426-1430. https://doi.org/10.1007/SpringerReference_21526

Ferdianto, F., \& Setiyani, S. (2018). Pengembangan Bahan Ajar Media Pembelajaran Berbasis Kearifan Lokal Mahasiswa Pendidikan Matematika. JNPM (Jurnal Nasional Pendidikan 
Matematika), 2(1), 37-47.

Nurmita F. (2017). Pengembangan Bahan Ajar Siswa dan Buku Guru Berbasis Matematika Realistik untuk Meningkatkan Pengetahuan, Sikap, dan Keterampilan Matematika Siswa Kelas VII SMP Al Karim Kota Bengkulu.

Prastowo. (2012). Panduan Kreatif Membuat Bahan Ajar Inovatif. Jogjakarta: DIVA Press.

Sugiyono. (2017). Metode Penelitian Kuantitatif, Kualitatif, dan R\&D. Bandung: Alfabeta.

Sumarmi, \& Amiruddin. (2014). Pengelolaan Lingkungan Berbasis Kearifan Lokal. Malang: AdityaMediaPublishing.

Susanto. (2013). Teknik Penyusunan Buku Ajar. In In Penyusunan Buku Ajar(p. 16). Semarang: Universitas Muhammadiyah. 